\title{
CONFLICTING RESULTS IF THE RUSSIAN DEFENCE SECTOR
}

\author{
V.Zatsepin
}

Departmental statistics of growth in production in the defense sector is highly distorted by liberalization of requirements to fulfilment of the state defense order on the part of the Ministry of Defense and the MilitaryIndustrial Commission. Despite the international sanctions, in 2015 the goal of the state armament program has been attained ahead of time, while the program actually ceased to be relevant. Fulfilment of the RF President's requirements to create a transparent defense economy and sort things out both in management of the militaryindustrial complex and pricing still encounters serious obstacles.

On one side, one cannot but be pleased with results achieved by the Russian military-industrial complex (MIC) by now, but on the other side, those results are questionable.

The data of the report of the Ministry of Industry and Trade of the Russian Federation published just before the final meeting of the Collegium of the above Ministry on 17 July $^{1}$ specifies and complements substantially the main results of the military-industrial complex in 2014; the above results were announced by RF Premier D. Medvedev at the State Duma on 21 April2 $^{2}$.

According to above data, growth in the defense and industrial complex amounted in general to $15.5 \%$, which was 2 p.p. higher than in 2013. It is to be noted that growth in output was observed in all the sectors of the military-industrial complex, in particular: the radio electronics industry $(24 \%)$, the aircraft industry (17.1\%), shipbuilding (14.4\%), production of ammunition and special chemicals (13\%), the rocket and space industry $(8.6 \%)$ and the conventional weaponry industry (5.4\%). Comparison of the above departmental data with the indices of the physical volume of production specified in the detailed lay-out published by the Rosstat early in April ${ }^{3}$ confirms to the extent possible the declared growth in all the subsectors of the military-industrial complex, except for shipbuilding where a drop of $17.1 \%$ in output was registered by the official state statistics. A slump in that subindustry was registered by the Rosstat for two years running (5.7\% in 2013) and in addition to that it was indirectly

1 The Report on the Goals and Objectives of the Ministry of Industry and Trade of the Russian Federation in 2015 and the Main Results of Activities in 2014. URL: http://minpromtorg.gov.ru/common/upload/files/docs/Minpromtorg_to_web_4\%5B1\%5D.pdf (date of application: 17.06.2015).

2 The Report on the Results of Work in 2014. URL: http://government.ru/news/17768/ (date of application: 21.04.2015).

3 Indices of the physical volume of gross value added by the type (as \% of the previous year). URL: http://www.gks.ru/free doc/new_site/vvp/tab12a.xls (date of application: 22.04.2015). confirmed by mass media's reports on a failure of the state defense order (SDO) of the Ministry of Defense of the Russian Federation ${ }^{4}$.

The data of the report of the Ministry of Industry and Trade of the Russian Federation is incomplete as regards the number of workers of the military-industrial complex and covers only three subindustries the radio electronics industry, aircraft industry and shipbuilding - where in 2014 the annual average number of workers amounted to 754,000 persons having decreased by $15,000(2 \%)$ as compared to the previous year. However, as early as January 2015 growth in the number of workers - by 4,600 persons - was registered in shipbuilding, obviously, due to inclusion of the Crimean shipbuilding companies in the register of the military-industrial complex.

As was already stated, it is more difficult to assess the results of the Russian defense sector in 2014 than a year before ${ }^{5}$. Firstly, from April 2014 the Ministry of Industry and Trade of the Russian Federation gave up its long-standing practice of publication of the quarterly statistics of the military-industrial complex and, secondly, additional deadlines set by the Ministry of Defense of the Russian Federation to entities of the military-industrial complex for liquidation of a 3\% incompleteness of the 2013 SDO "not later than Q1 2014" ${ }^{\prime \prime}$ happened to be extended already by six months this year ${ }^{7}$. If in 2014 the output of the militaryindustrial complex thanks to that privileged quarter

4 Weak Units in the Security System // The Independent Military Review.2014. 26 December; For a failure to fulfill the SDO, violatorenterprises will be fined - The Ministry of Defense of the Russian Federation // Interfaks- AVN. 2015. 16 July.

5 Russian Economy in 2014. Trends and Prospects (Issue 36) M.: The Gaidar Institute, 2015. - P. 553.

6 Fulfillment of Measures of State Defense Order in 2013. Round Table // RIA Novosti. 2013. 20 November. URL: http://pressmia. ru/pressclub/20131120/948684789.html (date of application: 16.07.2015).

7 Deputy Minister of Defense: Dynamic Equipment of Armed Forces Has Become a World Trend // Russian News Service. 24 January 2015. 
from January till June rose by 3.5 p.p., in 2015 such growth in output, probably, continued in June, too, because the data in the text of the above June report of the Ministry of Industry and Trade of the Russian Federation were declared as the preliminary one. It is fairly natural to suggest that in 2015 the effect of such a practice will be much greater than a year ago.

However, speaking before the deputies of the State Duma on 1 July $^{1}$, Vice-Premier D. Rogozin confirmed the above-stated figures of growth pointing to the fact that the aggregate revenues of the military-industrial complex rose by $29.4 \%$ in 2014 . Answering the question of Deputy D. Gorovtsov as regards the results of fulfilment of the state armament program (SAP) on equipment of the armed forces with modern samples of military hardware, D. Rogozin said that "in 2015 not $30 \%$ (as was originally planned) of rearmament, but $42 \%$ was achieved" ${ }^{\prime \prime}$. That rather startling statement meant that with taking into account the growth rates achieved by the end of the year the share of modern samples may amount to $45 \%$, that is, the target goal of the 2015 state armament program would be exceeded by $50 \%$. It remains to be seen whether that is a confirmation of success or failure of the state armament program?

If one believes the words of V. Chistova, Deputy Chairman of the Accounts Chamber of the Russian Federation who took the floor after D. Rogozin - there are no grounds to call her words in question - it is an unambiguous failure. As a system-level problem related to spending of $25 \%$ of the federal budget allocated on the SDO in a broader definition (military hardware and equipment, food, kits and building), V. Chistova pointed out to "the problem of incompliance of the 2011-2020 state armament program with annual sections of the state defense order" where the published amount of Rb 20 trillion till 2020 and "annual sections of the state defense order by the nomenclature, cost and other disagree to a great extent from year to year and the further, the greater" ${ }^{\prime \prime}$.

V. Chistova said that due to the fact that quantitative and qualitative parameters of the military hardware and equipment which was being developed, purchased and repaired were unavailable in supplements to the law on the budget "the armament program turned into a strategic long-term forecast which in practical terms became an irrelevant one" and the Accounts Chamber had plenty of evidence of the fact that high priority positions of the state armament pro-

1 Records of meetings of the State Duma on 1 July 2015. URL: http://transcript.duma.gov.ru/4314 (date of application: 14.07.2015)

2 Ibid.

3 Here and elsewhere the quotes are taken therefrom. gram were absent in the annual section of the SDO and "if efforts had been taken earlier to realize those positions, the problems related to lowering of dependence on import would have been less topical today".

Two weeks later, in carry out of the single day of acceptance of the military equipment by the Ministry of Defense it was reported to President V. Putin that the share of modern samples at present both by armament systems and types and branches of armed forces of the Russian Federation amounted to $30.5-70.7 \%$, so, the goal of the 2015 state armament program was achieved by all the armament systems, while the goal of 2020 , by some of them ${ }^{4}$. However, V. Chistova's statement that "the future program of armament which is being developed by the military-industrial commission should be a priority strategic document" is worth paying a particular attention to.

As it is known, at its meeting in January the military-industrial commission failed to approve the wellbalanced option of provision with resources the next state armament program for the 2016-2025 period due to a "floating" macroeconomic forecast, said VicePremier D. Rogozin after the meeting of the militaryindustrial complex ${ }^{5}$. Undoubtedly, in present conditions the long-term forecast is infeasible, but it was infeasible five years ago, too, when the existing state armament program was prepared - none of the official forecasts for 2010 could predict a serious slowdown of the economy by 2014 which slowdown was observed even before introduction of sectorial sanctions last year and depreciation of oil prices.

So, one should not overestimate the feasibility of such plans and their competence in principle "to take into account the financial and economic potential of the state" ${ }^{\prime \prime}$. The state of equilibrium is ensured by bureaucratic games, but not the quality of plans proper. It became explicit five years ago when the Ministry of Defense managed to change easily the limit of funding from $\mathrm{Rb} 13$ trillion to $\mathrm{Rb} 20$ trillion by giving rose-colored promises to rearm completely the armed forces. Certainly, it became apparent that the military overestimated substantially in its plans the potential of the Russian military and industrial complex on the one side and simultaneously left it without orders after 2020, on the other side, but it was already late - in the existing system of state management reversing is actually excluded the more so that both the state armament program and military

4 The Ministry of Defense: the share of modern armaments in the armed forces exceeded 30\% // RIA Novosti. 16 July 2015.

5 Rogozin: the deadlines of orders on the RF armament program may be extended // RIA Novosti. 20 January 2015.

6 The meeting of the Military and Industrial Commission. NovoOgarevo, 20 January 2015. URL: http://state.kremlin.ru/commission/41/news/47493 (date of application: 21.01.2015). 
expenses became a top priority for many people in Russia.

In the present economic conditions, it has become clear that the existing format of the state armament program despite its similarity with Soviet five-year plans is not viable - it is infeasible to make forecasts for more than 1-2 years - and requires introduction of the mechanism of official annual revision of that program.

Neither the new system of control over fulfilment of the SDO with "coloring" of the allocated budget funds",

1 Federal Law No. 159-FZ of 29 June 2015 of the Russian Federation on Amendment of the Federal Law on the State Defense Order and Individual Statutory Acts of the Russian Federation. nor strong statements in respect of the red tape in vertically integrated structures will help resolve the wellknown problems of the Russian defense sector caused by the excessive presence of the state. It is to be noted that at present the transparency of the sector, open statistics, open SDO and state armament program and, consequently, a transparent federal budget, that is, the main instruments of the state management are underestimated and ignored in Russia. It seems that at present the situation is apprehended only by the Accounts Chamber. 